\title{
Pengaruh Penambahan Serat Batang Pisang Ketip dan Filler Dedak Padi Terhadap Density, Kekuatan Bending dan Tarik Kompositcore, Sandwich dengan Skin Plywood
}

\author{
Salman, Ahmad Fadly \\ Jurusan Teknik Mesin, Fakultas Teknik, Universitas Mataram, Jl. Majapahit. No. 62, Mataram, NTB, 83125 \\ Telp.: (0370 636126), Fax: (0370) 636126 \\ E-mail: salmanrm@yahoo.com
}

\begin{abstract}
Fiber-reinforced composite core banana stems with additional filler of husk powder is another way to obtain the expected mechanical behavior of the composite. The aim of this study was to analyze the effect of fiber volume fraction content to density, bending strength and tensile strength of sandwich composite. Preparation of composite was done by hand lay-up method. Composite material used by banana ketip fiber and addition of husk powder with variation of fiber volume fraction were 7, 10, and $13 \%$ where husk was constant at 5\% with random fiber direction. Tests were conducted by referring to the density est standard (ASTM C 271), bending est (ASTM C 393) and tensile test (ASTM D3039). The result showed that the greater volume fraction of banana fiber, the lower the density value and the lower the bending strength. Whereas the tensile strength tended to increase as the volume fraction was higher.
\end{abstract}

Keywords: Composite, volume fraction, bending strength, tensile strength

\begin{abstract}
Abstrak
Pembuatan komposit core berpenguat serat batang pisang dengan filler serbuk dedak padi merupakan terobosan untuk mendapatkan kekuatan material yang baru. Penelitian ini bertujuan menganalisis pengaruh kandungan fraksi volume serat batang pisang ketip dengan filler dedak padi terhadap density, kekuatan bending dan kekuatan tarik komposit core dan sandwich. Pembuatan komposit dilakukan dengan metode hand lay-up. Variasi fraksi volume serat 7, 10,dan 13\% dan tambahan serbuk dedak padi sebesar 5\% konstan dengan arah serat acak. Pengujian yang dilakukan mengacu pada standar uji density (ASTM C 271), uji bending (ASTM C 393) dan Uji tarik (ASTM D3039). Dari hasil pengujian diperoleh semakin besar fraksi volume serat pisang, maka semakin rendah nilai density, semakin rendah kekuatan bendingnya. Sedangkan nilai tegangan tariknya makin tinggi.
\end{abstract}

Kata kunci: Komposit, Fraksi volume, Kekuatan bending, Kekuatan tarik.

\section{PENDAHULUAN}

Dibanding material logam, komposit memiliki sifat mekanik kekuatan bisa diatur (tailorability), kekuatan lelah (fatigue) yang tinggi, sifat isolator panas dan suara yang baik, dan dapat juga digunakan untuk menambal kerusakan akibat pembebanan dan korosi (Sirait, 2010).

Serat alam merupakan alternatif komposit selain polimer karena keunggulannya dibanding serat sintetis. Serat alam mudah didapatkan dengan harga yang murah, mudah diproses, densitasnya rendah, ramah lingkungan, dan dapat diuraikan secara bahan (Kusumastuti, 2009). Serat alam yang cocok digunakan sebagai serat dan filler komposit antara lain batang pisang dan dedak padi. Adapun skin yang umum digunakan yaitu plywood.

Komposit sandwich merupakan material yang tersusun dari tiga material atau lebih yang terdiri dari skin dan core di bagian tengahnya. Jika digunakan perekat untuk menggabungkan skin dan core, maka lapisan bahan perekat diperhitungkan sebagai komponen tambahan. Untuk mendapatkan struktur sandwich yang memiliki sifat mekanis tinggi maka diperlukan jenis skin dan core yang tepat. Dalam struktur sandwich, fungsi utama skin antara lain sebagai pelindung core dari benturan, gesekan dan memperbaiki penampilan (Steeves dan Fleck, 2004).

Sejumlah peneliti telah mengulas sifat mekanik sandwich berpenguat pelepah pisang dengan core kayu biti seperti yang dilakukan oleh Endrian (2015). Diperoleh nilai kekuatan tarik dan kekuatan bending komposit serat pelepah pisang ditambah dengan core kayu biti dipengaruhi oleh variasi volume core kayu biti serat pelepah pisang matriks resin.

Di lain pihak Nopriantina (2013) menggunakan pelepah pisang kepok untuk meneliti pengaruh ketebalan serat terhadap sifat mekanik material 
komposit polyester serat alam. Diperoleh adanya hubungan linier antara ketebalan serat terhadap tekanan yang diberikan terhadap kekuatan tekan komposit

Boimau (2010) juga mendapati pengaruh yang siginifikan dari panjang serat dan fraksi volume terhadap sifat bending komposit polyester yang diperkuat serat batang pisang dengan panjang serat 2 dan $5 \mathrm{~cm}$. dengan variasi fraksi volume serat yang digunakan sebesar 20,30, dan 40\%. Hasil penelitian menunjukan bahwa kekuatan bending komposit polyester meningkat seiring dengan meningkatnya fraksi volume serat.

Jumlah lamina juga didapati memiliki pengaruh terhadap kekuatan bending komposit sandwich serat aren dengan core pelepah pisang seperti yang diteliti oleh Wijoyo (2014). Diperoleh peningkatan kekuatan bending komposit sandwich serat aren polyester dengan core pelepah pohon pisang dengan variasi jumlah lamina. Penelitian dilakukan dengan bahan utama serat aren, matrik polyester type 157 BQTN dan G3253, katalis MEKFO, akselarator cobalt naphtenate, max way, wax/miror, dan core limbah pelepah pohon pisang. Hasil dari penelitian menunjukkan bahwa semakin banyak jumlah lamina komposit sandwich mengakibatkan kekuatan bending-nya juga semakin meningkat. Kekuatan bending komposit sandwich serat aren-polyester dengan core pelepah pohon pisang berbanding lurus dengan penambahan variasi jumlah lamina yang diberikan.

Demikian juga yang diperoleh Ojahan (2018) yang menganalisis pengaruh fraksi volume serat pelepah batang pisang bermatriks Unsaturated Resin Polyester (UPR) terhadap kekuatan tarik dan SEM pada material komposit berpenguat (fiber) serat batang pisang kepok. Hasilnya kekuatan tarik yang paling optimal terdapat pada volume fraksi $28 \%$ fiber, $72 \%$ matriks dengan gaya maksimum 2327,9 $\mathrm{N}$, tegangan tarik $67,206 \mathrm{~N} / \mathrm{mm}^{2}$, regangan $2,747 \%$ serta modulus elastisitas $3441,82 \mathrm{~N} / \mathrm{mm}^{2}$

Namun dari semua penelitian di atas belum ada yang menggabungkan antara bahan serat alam batang pisang ketip, filler dedak padi terhadap kekuatan mekanik komposit sandwich dengan skin plywood.

Karena itulah tujuan dilakukannya penelitian ini adalah untuk menganalisis pengaruh kandungan fraksi volume serat batang pisang ketip dengan filler dedak padi terhadap density, kekuatan bending dan kekuatan tarik komposit core dan sandwich.

\section{METODE}

Metode yang digunakan adalah eksperimen dengan mengguankan alat alat utama seperti cetakan alat dan pengepres, timbangan digital, alat uji bending, alat uji tarik, kamera, gelas ukur, mistar, gelas pencampur dan pengaduk, masker, sisir baja, gergaji, kuas, dan ember/bak.

Sedangkan bahan-bahan utama yang digunakan yaitu batang pisang, dedak padi, plywood, polyester tak jenuh (BQTN 157), katalis/hardner (Metyl Etyl Keton Peroksida/MEPOXE), aquades, larutan $\mathrm{NaOH}$ dengan konsentrasi 5\% dan epoxy.

Prosedur pengujian yaitu melakukan perlakuan serat batang pisang, penyiapan dedak, pembuatan cetakan, pembuatan spesimen, pengujian densitas, uji bending, uji tarik dan analisis ANOVA.

Perlakuan serat dilakukan dengan cara serat batang pisang ketip dipoong sepanjang $5 \mathrm{~cm}, \mathrm{NaOH}$ dicampur dengan air dengan kandungan $5 \%$ berat terhadap volume air. Selanjutnya serat batang pisang direndam dalam larutan $\mathrm{NaOH}$ selama 2 jam. Selanjunya serat yang telah direndam dicuci menggunakan air yang mengalir. Lalu serat batang pisang dikeringkan.

Tahap selanjutnya penyiapan dedak. Serbuk dedak padi diayak dengan ukuran 40 mesh.

Kemudian pembuatan cetakan. Cetakan dibuat dengan menggunakan plat baja dengan ketebalan cetakan $20 \mathrm{~mm}$ dan ukuran spesimen mengacu pada standar uji density ASTM C 271, uji bending ASTM C-393, dan kekuatan tarik (tensile strength) (ASTM C 297.

Tahap berikutnya pembuatan spesimen. Komposisi komposit yaitu kandungan serat 7, 10 dan $13 \%$ dengan filler 5\% konstan. Polyester, filler dan hardener dituangkan pada cetakan secara merata untuk dasar komposit. Serat batang pisang yang telah ditimbang dan dipotong dimasukkan ke dalam campuran resin tersebut lalu diaduk merata, Selanjutnya bagian atas cetakan dilapisi dengan kertas transparan agar saat pelapisan tidak lengket dengan penutup cetakan. Bagian atas cetakan ditutup dengan baja dan didiamkan selama 24 jam.

Pengujian yang dilakukan yaitu uji density, bending dan tarik. Pengujian densitas serat dilakukan dengan menggunakan timbangan dan gelas ukur sesuai dengan standar ASTM C271. Densitas dihitung menggunakan Persamaan (1).

$$
\rho=\frac{m}{v}=\frac{g}{\operatorname{lw} t}
$$

Di mana

$$
\begin{array}{ll}
\rho & =\text { Densitas }\left(\mathrm{kg} / \mathrm{m}^{3}\right) \\
m & =\text { Massa akhir }(\mathrm{gram}) \\
l & =\text { Panjang akhir }(\mathrm{mm}) \\
w & =\text { Lebar akhir }(\mathrm{mm}) \\
t & =\text { Tebal akhir }(\mathrm{mm})
\end{array}
$$

Kekuatan bending adalah tegangan bending terbesar yang dapat diterima akibat pembebanan luar tanpa mengalami deformasi yang besar atau kegagalan. Akibat pengujian bending, pada bagian atas spesimen akan mengalami tekanan, dan bagian bawah akan mengalami tegangan tarik. Material komposit kekuatan tekannya lebih tinggi terhadap 
tegangan tariknya. Kegagalan yang terjadi akibat pengujian bending, komposit akan mengalami patah pada bagian bawah yang disebabkan karena tidak mampu menahan tegangan tarik yang diterima.

Kekuatan bending komposit sandwich diukur dengan mengacu pada standar ASTM C-393 (lihat Gambar 1) menggunakan alat uji bending. Pada pengujian kali ini dilakukan dengan metode singlepoint bending (bending 1 titik). Dari percobaan ini akan diperoleh harga beban maksimum yang dapat diterima komposit sandwich. Kekuatan bending diukur menggunakan Persamaan (2).

$$
\tau=\frac{P_{\max }}{(d+c) b}
$$

Di mana :

$\tau=$ Kekuatan bending $(\mathrm{MPa})$

$P_{\max }=$ Beban maksimum $(\mathrm{N})$

$d=$ Tebal sandwich $(\mathrm{mm})$

$c \quad=$ Tebal inti (mm)

$b=$ Lebar sandwich $(\mathrm{mm})$

Sedangkan kekuatan tarik diukur menggunakan alat uji tarik UTM (lihat Gambar 2) menggunakan Persamaan (4) sesuai ukuran di Gambar 3.

$$
\sigma=\frac{P}{A}
$$

Di mana

$\sigma=$ Kekuatan tarik $(\mathrm{MPa})$

$A=$ Luas penampang $\left(\mathrm{mm}^{2}\right)$.

Selanjutnya hasil pengujian juga diuji analisi statistic secara ANOVA. model klasifikasi satu arah. Bila dari hasil perhitungan diperoleh $F_{\text {hitung }}$ lebih besar dari $F_{\text {tabel }}$ maka hipotesa nol $\left(H_{0}\right)$ ditolak dan hipotesis alternatif $\left(H_{1}\right)$ diterima.

\section{HASIL DAN PEMBAHASAN Uji Densitas}

Nilai density komposit core yang menunjukkan berat dan kepadatan spesimen komposit core ditunjukkan pada Tabel 1 . Sedangkan nilai density

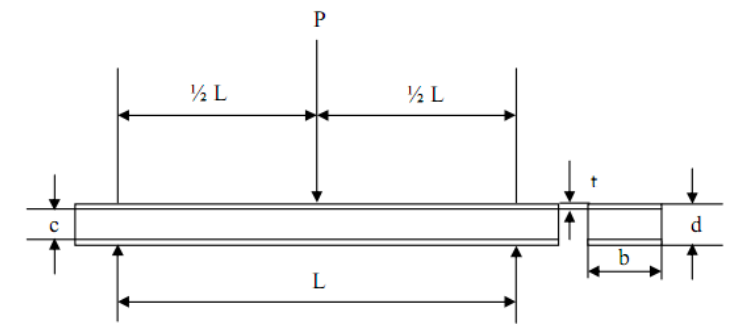

Gambar 1. Sketsa pengujian spesimen uji bending.

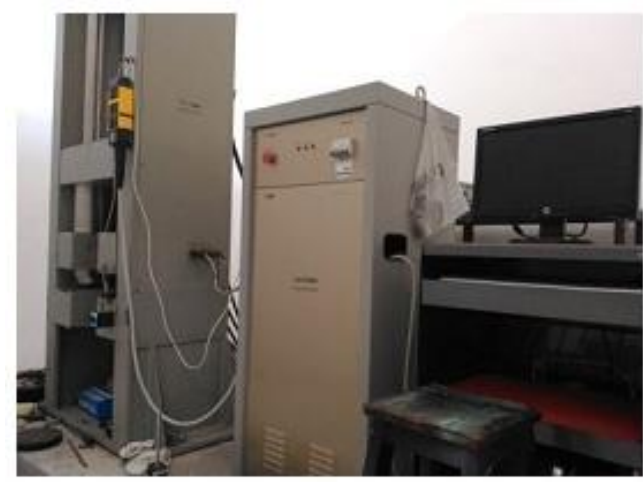

Gambar 2. Alat uji tarik UTM.

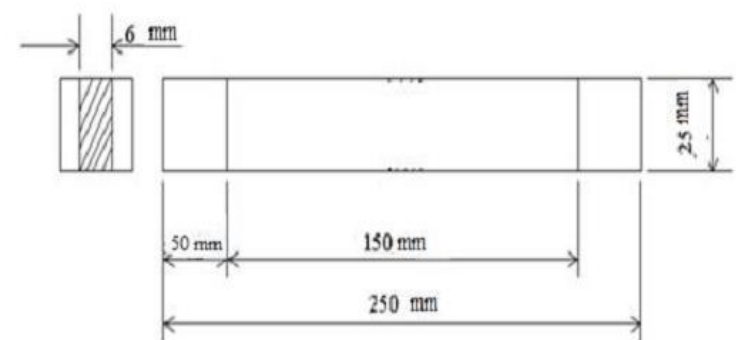

Gambar 3. Dimensi spesimen uji tarik.

Tabel 1. Data pengujian density komposit core.

$\begin{array}{ccccccc}\text { Fraksi } & m & b & d & c & V & \rho \\ & & \end{array}$

Volume $\quad(\mathrm{g}) \quad(\mathrm{mm}) \quad(\mathrm{mm}) \quad(\mathrm{mm}) \quad\left(\mathrm{cm}^{3}\right) \quad\left(\mathrm{g} / \mathrm{cm}^{3}\right)$

$(\%)$

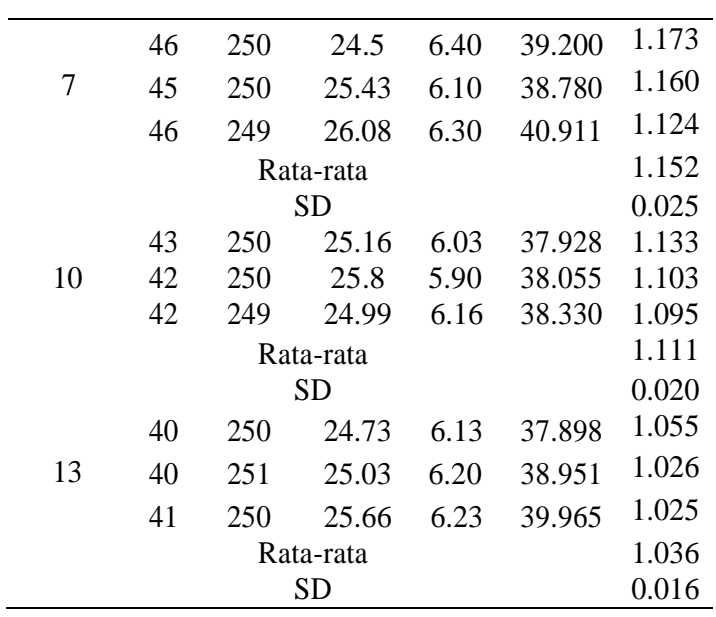

\begin{tabular}{|c|c|c|c|c|c|c|}
\hline $\begin{array}{c}\text { Fraksi } \\
\text { Volume } \\
(\%)\end{array}$ & $\begin{array}{l}m \\
(\mathrm{~g})\end{array}$ & $\begin{array}{c}b \\
(\mathrm{~mm})\end{array}$ & $\begin{array}{c}d \\
(\mathrm{~mm})\end{array}$ & $\begin{array}{c}c \\
(\mathrm{~mm})\end{array}$ & $\begin{array}{c}V \\
\left(\mathrm{~cm}^{3}\right)\end{array}$ & $\begin{array}{c}\rho \\
\left(\mathrm{g} / \mathrm{cm}^{3}\right)\end{array}$ \\
\hline \multirow{3}{*}{7} & 539 & 451 & 50.52 & 24.3 & 553.663 & 0.973 \\
\hline & 541 & 450 & 50.15 & 24.1 & 543.876 & 0.994 \\
\hline & 542 & 450 & 50.05 & 24.45 & 550.675 & 0.984 \\
\hline \multicolumn{6}{|c|}{ Rata-rata } & 0.984 \\
\hline \multirow{4}{*}{10} & & & SD & & & 0.010 \\
\hline & 526 & 450 & 50.07 & 24.65 & 555.401 & 0.947 \\
\hline & 524 & 451 & 50.1 & 24.67 & 557.421 & 0.940 \\
\hline & 524 & 450 & 50.1 & 24.65 & 555.734 & 0.942 \\
\hline \multicolumn{6}{|c|}{ Rata-rata } & 0.943 \\
\hline & & & SD & & & 0.003 \\
\hline
\end{tabular}

Tabel .2 Data pengujian densitas komposit sandwich . 


\begin{tabular}{|c|c|c|c|c|c|}
\hline \multirow{3}{*}{13} & 511 & 50.67 & 24.83 & 566.161 & 0.902 \\
\hline & 512 & 50.65 & 24.62 & 559.904 & 0.914 \\
\hline & 511 & 50.61 & 24.6 & 560.252 & 0.912 \\
\hline \multirow{2}{*}{\multicolumn{5}{|c|}{$\begin{array}{c}\text { Rata-rata } \\
\text { SD }\end{array}$}} & 0.909 \\
\hline & & & & & 0.006 \\
\hline
\end{tabular}

komposit sandwich ditunjukkan pada Tabel 2.

Semakin besar fraksi volume maka density komposit core dan komposit sandwich close sell semakin turun ini disebabkan oleh penggunaan serat yang tinggi setelah perlakuan $\mathrm{NaOH} 0.86 \mathrm{~g} / \mathrm{cm}^{3} \mathrm{dan}$ resin. Maka semkin besar penggunaan serat maka penggunaan resin semakin menurun dan ini mempengaruhi density komposit sandwich serat batang pisang dan filler dedak padi. Penurunan densitas akibat bertambahnya fraksi volume ini disebabkan terjadinya pemadatan tanpa rongga.

\section{Hasil Uji kekuatan Bending Komposit Sandwich}

Pengujian bending komposit sandwich dilakukan dengan metode three point bending. Data grafik hubungan beban dengan pertambahan panjang ditunjukkan pada Gambar 4.

Nilai beban berbanding lurus dengan perpanjangan. Fraksi volume serat $7 \%$ terlihat memiliki nilai beban terbesar yaitu $1190,13 \mathrm{~N}$ dengan perpanjangan sebesar 14,21 mm. Sedangkan beban terendah terdapat pada fraksi volume $13 \%$ yaitu 821,23 $\mathrm{N}$ dengan perpanjangan $12,11 \mathrm{~mm}$. Dengan demikian mempengaruhi juga nilai kekuatan bendingnya seperti ditunjukkan di Tabel 3.

Secara umum dapat dilihat bahwa fraksi volume serat berbanding terbalik dengan kekuatan bending. Semakin besar fraksi volume serat maka banbeban yang didapatkan justru semakin menurun.

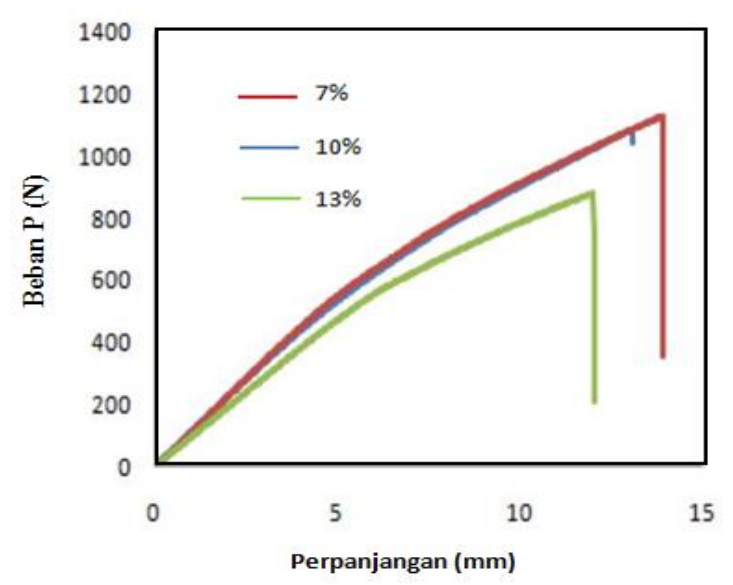

Gambar 4. Hubungan fraksi volume serat batang pisang ketip 7, 10 dan 13\% pada komposit terhadap perpanjangan spesimen.

Tabel 4. Data perhitungan kekuatan bending komposit sandwich berdasarkan fraksi volume serat batang pisang.

\begin{tabular}{|c|c|c|c|c|c|c|c|}
\hline $\begin{array}{c}\text { Fraksi volume } \\
(\%)\end{array}$ & $\begin{array}{c}\mathrm{c} \\
(\mathrm{mm})\end{array}$ & $\begin{array}{c}\mathrm{b} \\
(\mathrm{mm})\end{array}$ & $\underset{(\mathrm{mm})}{\mathrm{d}}$ & $\begin{array}{c}\text { Defleksi } \\
(\mathrm{mm})\end{array}$ & $\begin{array}{c}P \\
(\mathrm{~N})\end{array}$ & $\begin{array}{c}\tau \\
(\mathrm{Mpa})\end{array}$ & $\begin{array}{c}\sigma_{\mathrm{b}} \\
(\mathrm{Mpa})\end{array}$ \\
\hline \multirow{5}{*}{7} & 18.30 & 50.52 & 24.30 & 19.81 & 1517.52 & 0.71 & 47.01 \\
\hline & 18.10 & 50.15 & 24.10 & 15.00 & 1284.33 & 0.61 & 40.46 \\
\hline & 18.45 & 50.05 & 24.45 & 15.37 & 1263.21 & 0.59 & 39.22 \\
\hline & \multicolumn{3}{|c|}{ Rata-rata } & & & 0.63 & 42.23 \\
\hline & \multicolumn{3}{|c|}{ SD } & & & 0.06 & 04.18 \\
\hline \multirow{5}{*}{10} & 18.65 & 50.07 & 24.65 & 13.06 & 1085.49 & 0.50 & 33.38 \\
\hline & 18.67 & 50.10 & 24.67 & 13.90 & 1128.97 & 0.52 & 34.66 \\
\hline & 18.65 & 50.10 & 24.65 & 11.98 & 879.89 & 0.41 & 27.04 \\
\hline & \multicolumn{3}{|c|}{ Rata-rata } & & & 0.48 & 31.69 \\
\hline & \multicolumn{3}{|c|}{ SD } & & & 0.06 & 04.08 \\
\hline \multirow{5}{*}{13} & 18.83 & 50.67 & 24.83 & 08.27 & 599.96 & 0.27 & 18.08 \\
\hline & 18.62 & 50.65 & 24.62 & 09.37 & 850.87 & 0.39 & 25.90 \\
\hline & 18.60 & 50.61 & 24.60 & 18.07 & 939.30 & 0.43 & 28.64 \\
\hline & \multicolumn{3}{|c|}{ Rata-rata } & & & 0.36 & 24.21 \\
\hline & \multicolumn{3}{|c|}{ SD } & & & 0.08 & 05.48 \\
\hline
\end{tabular}

Hal ini karena pada proses pembuatan spesimen perbandingan komposisi resin dengan fraksi volume. Jumlah resin yang justru modal kekuatan bagi material. Ini karena resin mengikat serat lebih kuat disbanding jika resin yang digunakan dalam prosentase kecil. Akibatnya mempengaruhi kekuatan bending dari komposit sandwich yang menurun seiring bertambahnya prosentase fraksi volume serat.

Hal ini menarik karena hasilnya berbeda dengan yang diperoleh sejumlah peneliti sebelumnya. Seperti ditunjukkan oleh Endrian (2015), Nopriantina (2013), Boimau (2010), Ojahan (2015), Wijoyo (2014). Umumnya diperoleh peningkatan kinerja kekuatan bending komposit sandwich serat alam dengan core polyester.

Dari penelitian yang dilakukan ini menurunnya sifat mekanik komposit seiring bertambahnya jumlah fraksi volume serat batang pisang disebabkan karena 
pembuatan spesimen yang masih menggunakan handy lay out. Metode pembuatan komposit secara manual seperti ini memang ditengarai menciptakan banyak void pada bahan.

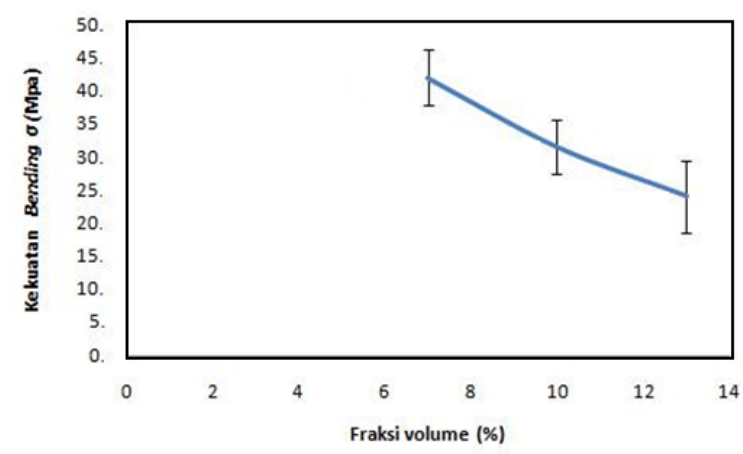

- Gambar 5. Grafik hubungan antara fraksi volume dengan kekuatan bending komposit sandwich.

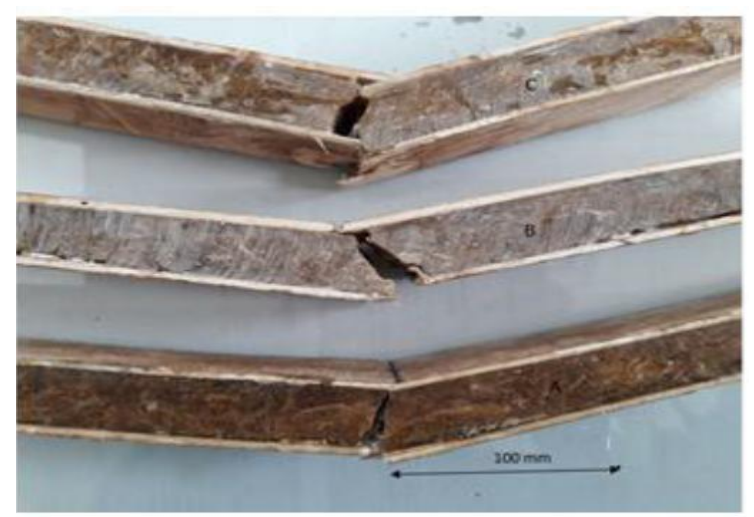

Gambar 6 Bentuk kegagalan spesimen dari pengujian bending.

Tabel 4. Hasil Perhitungan uji bending dengan ANOVA satu arah.

\begin{tabular}{cccccc}
\hline $\begin{array}{c}\text { Source of } \\
\text { Variation }\end{array}$ & $S S$ & $D f$ & $M S$ & $F_{\text {hitung }}$ & $F t_{\text {abel }}$ \\
\hline $\begin{array}{c}\text { Fraksi } \\
\text { volume }\end{array}$ & 491.8231 & 2 & 245.9116 & 11.49111 & 5.143253 \\
Eror & 128.4009 & 6 & 21.40015 & & \\
& & & & & \\
Total & 620.224 & 8 & & & \\
\hline
\end{tabular}

Void inilah yang memicu munculnya delaminasi sepanjang sisi void. Apalagi disertai penambahan filler dedak pada bahan.

Dari data di atas didapat hubungan antara tegangan bending dengan fraksi volume seperti ditunjukkan Gambar 5. Nilai kekuatan bending komposit sandwich cenderung menurun seiring dengan bertambahnya fraksi volume. Kekuatan bending terendah pada fraksi volume $13 \%$ dengan nilai sebesar 24,21 Mpa. Penurunan ini terjadi karena penggunaan resin pada fraksi $7 \%$ lebih banyak dibandingkan dengan fraksi yang lebih besar sehingga mengakibatkan kekuatan cendrung menurun. Kegagalan terjadi pada spesimen dimulai dari tengah dan terjadi patahan dimulai dari skin bawah kemudian menuju inti. Setelah terjadi patahan beban mulai menurun (lihat Gambar 6).

\section{Analisis ANOVA Uji Bending}

Dari Tabel 4 analysis of variances ditunjukkan bahwa untuk uji bending komposit sandwich di mana $F_{\text {hitung }}>F_{\text {tabel }}$ maka $H_{0}$ ditolak. Sehingga fraksi volume berpengaruh terhadap kekuatan bending komposit sandwich dengan serat batang pisang ketip dengan filler dedak padi.

\section{Hasil Uji kekuatan Tarik Komposit Sandwich}

Hasil pengujian tarik menunjukkan adanya hubungan antara fraksi volume serat dengan kekuatan tarik komposit.

Nilai kekuatan tarik rata-rata meningkat seiring dengan bertambahnya fraksi volume serat. Nilai tertinggi terdapat pada fraksi volume $13 \%$ dengan nilai 21,10 MPa. Sedangkan nilai terendah terdapat pada fraksi volume 10\% dengan nilai 17,50 MPa.

Yang menarik dari hasil uji tarik ini adalah hasilnya berlawanan dengan sifat yang ditunjukkan pada uji bending. Bila pada bending nilainya menurun seiring bertambahnya jumlah fraksi, maka tidak demikian dengan yang diperoleh di uji tarik yang justru meningkat seiring bertambahnya fraksi

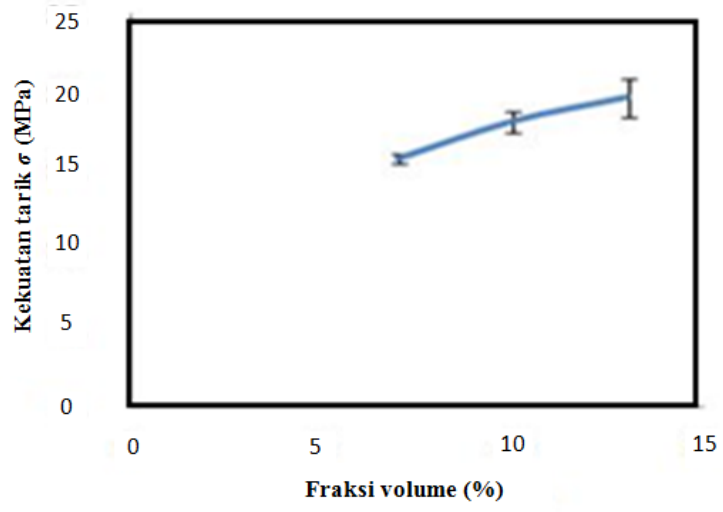

Gambar 7. Kekuatan tarik berdasarkan fraksi volume serat pada komposit.

volume serat (lihat Gambar 7).

Di sinilah letak peran serat alam pada komposit. Yaitu meningkatkan kinerja mekanik bahan terutama pada kekuatan tariknya. Ini karena serat memegang matriks saat diberikan penambahan beban tarik. Jadi meski pertambahan panjang atau elongation terjadi namun bahan tidak mengalami kegagalan sampai jauh melewati titik yielding bahkan masih tetap elastic sampai benar-benar menemui titik jenuh pada level patah.

Patahan bisa terjadi dekat kulit pencengkram 
atau pada bagian tengah. Hal ini akibat pengaruh tingkat distribusi serat pada spesimen. Pada bagian yang tidak merata umumnya timbul void yang melemahkan bahan yang menerima beban statik dan dinamik sehingga menimbulkan tegangan. Akibat selanjutnya pada bagian tersebut terjadi delaminasi, pada pembebanan lanjut mengakibatkan patah sama sekali (lihat Gambar 8).

\section{Analisis ANOVA Uji Tarik}

Dari Tabel 5 ANOVA terlihat bahwa untuk uji tarik komposit core diperoleh $F_{\text {hitung }}>F_{\text {tabel }}$ maka $H_{0}$ ditolak. Jadi fraksi volume berpengaruh terhadap

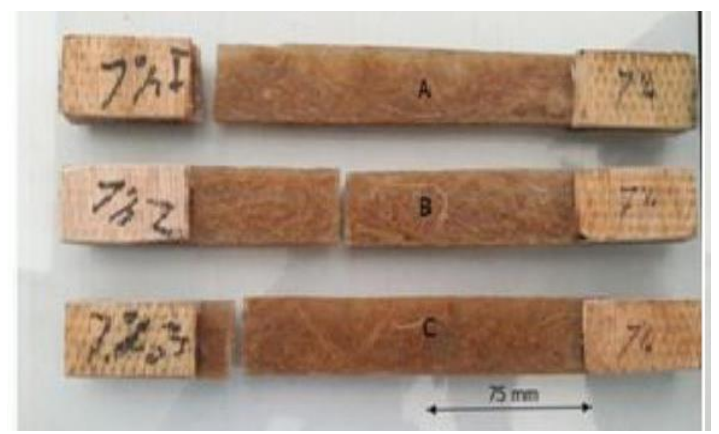

Gambar 8. Bentuk kekagalan komposit core dari uji.

kekuatan tarik komposit core dengan serat batang pisang ketip dan filler dedak padi.

\section{KESIMPULAN}

Dari hasil pengujian bending dan tarik komposit sandwich berserat batang pisang dengan filler dedak padi, diperoleh phenomena menarik yaitu penambahan fraksi volume akan bisa menurunkan nilai kekuatan bending bahan komposit.

Di lain pihak justru akan meningkatkan nilai kekuatan tariknya sampai pada jumlah fraksi volume tertentu.

Namun yang perlu dicatat hasil uji tarik ini tidaklah perlu dijadiklna patokan karena dari pengujian ditemui fakta bahwa pembuaan spesimen menggunakan metode handy lay out-lah yang menyebabkan "penyimpngan hasil" yang tak diharapkan ini.

Karena peneliti-peneliti sebelumnya secara konsisten memperoleh kesimpulan bahwa penambahan jumlah fraksi volume serat akan menaikkan sifat kekuatan bendingnya.

Jadi bisa disimpulkan bahwa jika menggunakan metode pembutan spesimen yang lebih komprehensif akan jga menaikkan sifat kekuatan bendingnya.

\section{UCAPAN TERIMA KASIH}

Terimakasih kami ucapkan kepada semua pihak yang telah membantu kelancaran penelitian ini.

\section{DAFTAR PUSTAKA}

- Jurnal Ilmiah:

[1] Endrian, N., 2015, “Analisis Sifat mekanik Komposit Sandwich Serat Pelepah Pisang dengan Core Kayu Biti”, Jurnal Andounohu, Vol. 6(2), 12-19.

[2] Kusumastuti, A., 2009, “Aplikasi Serat Sisal sebagai Komposit Polimer", Jurnal Kompetensi Teknik, Vol. 1(1), 3-9.

[3] Nopriantina, N.,2013, "Pengaruh Ketebalan Serat Pelepah Pisang Kepok Musa Paradisiaca Terhadap Sifat Mekanik Komposit Poliester Serat Alam", Jurnal MIPA Andalas, Vol. 2( 3), 11-17.

[4] Ojahan, T., 2018, “Analisis Serat Pelepah Batang Pisang Kepok Material Fiber Komposit Matriks Recycled Polypropylene (RPP) Terhadap Sifat Mekanik dan SEM", Jurnal Mahasiswa Teknik Malahayati, Vol.1 (1), 1218.

[5] Steeves C. A. \& Fleck, N.A., 2004, "Colllaps Mechanism of Sandwich Beam with Composite Face and Foam Core Loaded in Three Point Bending”, Science Direct, Vol. 23 (3), 23-30.

- Skripsi, Tesis, Disertasi, Laporan Penelitian:

[6] Boimau, K., 2010, "Pengaruh Fraksi Volume Dan Panjang Serat Terhadap Sifat Bending Komposit Poliester Yang Diperkuat serat Batang Pisang", Semnas Tahunan Teknik Mesin Ke-9 Jurusan Teknik Mesin, Universitas Cendana NTT.

[7] Wijoyo.,2014, "Pengaruh Jumlah Lamina Terhadap Kekuatan Bending Komposit Sandwich Serat Aren Poliester dengan Core Pelepah Pohon Pisang", Tugas Akhir, Program Studi Teknik Mesin, Fakultas Teknik, Universitas Surakarta.

- Buku, Buku terjemahan:

[8] Bismarck, 2002, Influence of alkali treatment on surface properties of fibers, Mc. Grawhill, New York.

- Internet (karya individual):

[9] Sirait, D. H., 2010, "Material Komposit Berbasis Polimer Menggunakan Serat Alam", diakses 5 Februari, 2017, dari http://dedyharianto.wordpress.com 